\title{
ANALISIS PENDAPATAN DAN STRATEGI PENGEMBANGAN USAHA TANI TEMBAKAU RAJANG SAMPORIS
}

\section{RAJANG SAMPORIS TOBACCO FARMING DEVELOPMENT STRATEGY AND INCOME ANALYSIS}

\author{
Wiwik Munawaroh $^{1)}$, Sugeng Raharto ${ }^{1)}$, dan Anik Suwandari ${ }^{1)}$ \\ 1) Agribisnis, Fakultas Pertanian Universitas Jember \\ email: wiwikmunawaroh16@gmail.com
}

\begin{abstract}
ABSTRAK
Tembakau rajang samporis merupakan tembakau dari persilangan sompor dan moris, di daerah Kecamatan Jelbuk yang sudah terjadi persilangan secara alami namun bagian kedinasan perkebunan dan kehutanan menyebutnya dengan tembakau maesan 1 sementara masyarakat tetap menyebutnya dengan sebutan tembakau samporis. Penelitian ini bertujuan untuk mengetahui: (1) pendapatan petani tembakau rajang samporis di Desa Jelbuk Kecamatan Jelbuk Kabupaten Jember; (2) efisiensi biaya usahatani tembakau rajang samporis di Desa Jelbuk Kecamatan Jelbuk Kabupaten Jember; (3) strategi pengembangan usahatani tembakau rajang samporis di Desa Jelbuk Kecamatan Jelbuk Kabupaten Jember. Penentuan daerah penelitian menggunakan purposive method. Metode yang digunakan dalam penelitian ini adalah metode deskriptif dan analitis. Metode pengambilan contoh menggunakan total sampling dengan responden sebanyak 31 petani. Analisis data menggunakan analisis pendapatan, analisis efisiensi biaya dan analisis SWOT . Hasil analisis menunjukkan bahwa:(1) usahatani tembakau samporis di Desa Jelbuk Kecamatan Jelbuk Kabupaten Jember adalah menguntungkan dengan rata-rata pendapatan sebesar $\mathrm{Rp}$ 2.089.242/ha/musim. (2) Penggunaan biaya produksi pada usahatani tembakau samporis di desa Jelbuk Kecamatan Jelbuk Kabupaten Jember adalah efisien dengan nilai sebesar 1,44. (3) Analisis SWOT pada usahatani tembakau samporis di Desa Jelbuk Kecamatan Jelbuk Kabupaten Jember berada pada posisi White Area (Bidang Kuat-Berpeluang).
\end{abstract}

Kata kunci: Tembakau Rajang samporis, pendapatan petani temabakau Rajang, strategi pengembangan

\section{ABSTRACT}

Rajang samporis tobacco is tobacco from crosses of sompor and moris, in Jelbuk subdistrict which has crossed naturally but the plantation and forestry department call it with tobacco maesan 1 while the community still call it as tobacco samporis. This study aims to determine: (1) the income of tobacco farmers cigarette sampler in Jelbuk Village Jelbuk District Jember District; (2) cost efficiency of tobacco-cutting tobacco farming in Jelbuk Village, Jelbuk Sub-district, Jember District; (3) strategy of development of tobacco farming of sampang chocolate in Jelbuk Village, Jelbuk Sub-district, Jember Regency. Determination of research area using purposive method. The method used in this research is descriptive and analytical method. Sampling method used total sampling with 31 respondents. Data analysis uses income analysis, cost efficiency analysis and SWOT analysis. The results of the analysis show that: (1) the sampling tobacco farming in Jelbuk Village Jelbuk Sub-district of Jember Regency is advantageous with the average income of IDR 2,089,242 / ha / season. (2) The use of production cost in tobacco farming in Jelbuk village Jelbuk sub-district Jember regency is efficient with value equal to 1.44. (3) SWOT analysis showing that the sampling tobacco farming in Jelbuk Village Jelbuk Subdistrict of Jember Regency is in White Area position (Strong-Potential Field).

Keywords: Rajang samporis tobacco, Income, Development strategy 


\section{PENDAHULUAN}

Tembakau memiliki peran yang cukup besar bagi masyarakat, karena aktivitas produksi dan pemasarannya melibatkan sejumlah penduduk untuk mendapatkan pekerjaan dan penghasilan. Berdasarkan data BPS produksi perkebunan tembakau di Jawa Timur 2015, dapat diketahui bahwa Kabupaten Jember merupakan Kabupaten yang memiliki jumlah produksi tembakau paling tinggi di Provinsi Jawa Timur pada tahun 2012, 2013 dan 2014. Tiga tahun berturut-turut Kabupaten Jember menjadi Kabupaten yang memiliki produksi tembakau tertinggi. Sementara Kecamatan Jelbuk merupakan kecamatan yang memiliki luas lahan $820 \mathrm{Ha}$, produksi $7,380 \mathrm{Kw}$ dan produktivitas $9 \mathrm{kw} / \mathrm{ha}$. Angka tersebut merupakan angka paling tinggi dari semua kecamatan di Kabupaten Jember menurut BPS dinas Perkebunan dan Kehutanan Kabupaten Jember2014.

$$
\text { Tembakau Rajang Samporis }
$$
merupakan persilangan Sompor dan Moris di daerah Kecamatan Jelbuk yang sudah terjadi persilangan secara alami namun bagian kedinasan perkebunan dan kehutanan menyebutnya dengan tembakau maesan 1 sementara masyarakat tetap menyebutnya dengan sebutan tembakau samporis. Ciri khas yang dimiliki oleh tembakau samporis yang ada di Desa Jelbuk Kecamatan Jelbuk Kabupaten Jember yaitu benih maupun bibit dari varietas ini tidak bisa ditemukan diwilayah lain maupun Dinas Perkebunan khususnya bagian pembibitan, karena anakan atau bibit tembakau samporis tersebut merupakan tembakau lokal yang ditanam oleh nenek moyang yang tinggal di Jelbuk sampai sekarang. Bibit tembakau tersebut kemudian dijadikan banyak anakan sehingga hanya tembakau samporis khas Kecamatan Jelbuk yang sangat cocok ditanam di wilayah tersebut khususnya Desa Jelbuk.

Pendapatan petani tembakau samporis yang hanya bisa menguntungkan dalam jumlah yang sedikit karena skala usahataninya dalam skala kecil. Hal tersebut karena minimya modal, sempitnya lahan yang dimiliki petani, terbatasnya sumber daya manusia yang masih menggunakan cara-cara yang kurang moderen dan teknologi yang kurang mendukung. Kemungkinan keuntungan yang sedikit akan menjadi lebih sedikit apabila petani tidak mampu untuk menghitung biaya-biaya pengeluaran usahatani secara terperinci seperti upah petani dalam keluarga, konsumsi para buruh tani, biaya irigasi dan biaya-biaya lainnya yang akan mengakibatkan petani merugi tanpa disadarinya. Kondisi alam yang sulit untuk diprediksi dan dicegah, biaya pupuk dan pestisida yang semakin mahal, dan penjualan tembakau berdasarkan kualitas menyebabkan petani harus lebih berhati-hati lagi dalam membudidayakan tanaman ini. Sehingga petani bisa memperoleh keuntungan sesuai dengan usaha dan kebutuhkannya. Untuk itu perlu menganalisis pendapatan yang diterima oleh petani tembakau samporis dengan cermat dan terperinci.

Tingginya biaya produksi membuat petani harus mampu berinovasi untuk menekan biaya produksi dan meningkatkan hasil panen serta kualitas tembakaunya. Harga tembakau tergantung pada kualitas daun yang dipanen, sehingga tembakau yang bagus menjadi salah satu alternatif yang bisa menjadikan harga tembakau tetap stabil meskipun dalam keadaaan harga yang sedang turun. Dalam hal ini petani harus bisa melakukan budidaya tembakau samporis dengan baik, tepat waktu, guna, dan cara. Selain itu, antisipasi gagal panen yang terjadi akibat dari hal-hal yang tidak diinginkan, juga harus dipersiapkan dengan cara menekan biaya usahatani. Sehingga mengefisienkan biaya usahatani tembakau samporis secara maksimal menjadi cara yang tepat untuk menghindari kerugian yang mungkin bisa dialami dan juga dapat meningkatkan pendapatan yang diterima oleh petani. 
Kualitas tembakau samporis yang dihasilkan bervariasi setiap tahunnya yang berdampak pada harga jual yang fluktuatif. Apabila kualitas tembakau samporis yang dihasilkan rendah, maka harga jualnya juga rendah sehingga petani akan mengalami kerugian yang besar. Dengan demikian perlu untuk mengidentifikasi strategi pengembangan tembakau samporis dengan menggunakan analisis SWOT agar potensipotensi yang dimiliki oleh tembakau samporis di Desa Jelbuk Kecamatan Jelbuk bisa terus dikembangkan. Berdasarkan uraian tersebut, maka tujuan yang akan dikaji yaitu pendapatan usahatani tembakau rajang samporis, efisiensi biaya usahatani tembakau rajang samporis, dan strategi pengembangan usahatani tembakau rajang samporis di Desa Jelbuk Kecamatan Jelbuk Kabupaten Jember.

\section{METODE PENELITIAN}

Penentuan lokasi penelitian dilakukan secara sengaja (Purposive methods). Lokasi penelitian adalah di Desa Jelbuk Kecamatan Jelbuk Kabupaten Jember dengan pertimbangan. (1) Kecamatan Jelbuk merupakan wilayah yang produksi tembakau rajangnya terbesar di Kabupaten Jember. (2) Desa Jelbuk Merupakan desa penghasil tembakau samporis terbesar ke-3 di Kecamatan Jelbuk Kabupaten Jember. (3) Desa Jelbuk Merupakan desa yang memiliki kelompok tani yang lebih aktif dari desa lainnya.

Metode yang digunakan adalah metode deskriptif dan analitik. Metode pengambilancontohyang digunakan pada penelitian menggunakan metode Total Sampling. Metode total sampling merupakan teknik pengambilan sampel dimana jumlah sampel sama dengan populasi. Kelompok tani Sumber Makmur 2 merupakan kelompok tani yang menjadi sampel dalam penelitian ini dengan jumlah anggota 31 orang. Hal tersebut karena kelompok tani sumber makmur 2 memiliki jumlah petani yang menanam tembakau rajang samporis paling banyak dari kelompok tani lain. Selain itu
Kelompok tani tersebut juga merupakan kelompok tani paling aktif dari kelompok tani yang lain yang ditunjukkan dari adanya kegiatan pertemuan rutin setiap 2 minggu sekali yang membahas tentang masalahmasalah usahatani mereka dengan memecahkan masalah bersama-sama. Sementara pengambilan contoh selain petani yaitu PPL Perkebunan dan Kehutanan Desa Jelbuk Kecamatan Jelbuk Kabupaten Jember, Pamung Tani Desa Jelbuk dan ketua Gapoktan sekaligus Ketua Kelompok Tani Sumber Makmur 2 di Desa Jelbuk.

Untuk menjawab permasalahan pertama mengenai pendapatan usahatani tembakau rajang samporis menggunakan analisis pendapatan dengan formulasi sebagai berikut (Soekartawi, 1995):

$$
\mathrm{Pd}=\mathrm{TR}-\mathrm{TC}
$$

Keterangan:

$$
\begin{array}{ll}
\text { Pd } & \text { : pendapatan usahatani } \\
\text { TR } & \text { : total penerimaan } \\
\text { TC } & \text { : total biaya }
\end{array}
$$

Kriteria pengambilan keputusan:

a. TR>TC, menunjukkan bahwa usahatani mangga gadung menguntungkan.

b. $\mathrm{TR}=\mathrm{TC}$, menunjukkan bahwa usahatani mangga gadung adalah impas.

c. TR < TC, menunjukkan bahwa usahatani mangga gadung tidak menguntungkan.

Untuk menjawab permasalahan kedua mengenai efisiensi penggunaan biaya produksi tembakau samporis menggunakan analisa $\mathrm{R} / \mathrm{C}$ ratio. Analisis efisiensi biaya produksi dapat dinyatakan dalam persamaan sebagai berikut: ( Hernanto, 1996).

$$
\mathrm{R} / \mathrm{C} \text { ratio }=\frac{\mathrm{TR}}{\mathrm{TC}}
$$

Keterangan:

$\mathrm{TR}=$ total penerimaan $(\mathrm{Rp})$

$\mathrm{TC}=$ total biaya $(\mathrm{Rp})$

Kreteria pengambilan keputusan :

a. $\mathrm{R} / \mathrm{C}$ ratio $>1$, berarti penggunaan biaya efisien.

b. $\mathrm{R} / \mathrm{C}$ ratio $\leq 1$, berarti penggunaan biaya tidak efisien. 
Sementara untuk menemukan jawaban permasalahan ketiga mengenai prospek pengembangan usahatani tembakau samporis di Desa Jelbuk Kecamatan Jelbuk Kabupaten Jember menggunakan analisis SWOT.

Tabel 1. Analisis Faktor Internal (IFAS)

\begin{tabular}{|c|c|c|c|c|}
\hline $\begin{array}{l}\text { Faktor-Faktor } \\
\text { Strategi Internal }\end{array}$ & Bobot $^{1}$ & Rating $^{2}$ & $\begin{array}{c}\text { Nilai } \\
\text { (bobot } x \text { rating) }\end{array}$ & Komentar \\
\hline $\begin{array}{l}\text { Kekuatan } \\
\text { Kelemahan }\end{array}$ & & & & \\
\hline
\end{tabular}

Sumber: Analisis SWOT Teknik Membedah Kasus Bisnis, 2006

Tabel 2. Analisis Faktor Eksternal (EFAS)

\begin{tabular}{|c|c|c|c|c|}
\hline $\begin{array}{c}\text { Faktor-Faktor } \\
\text { Strategi Eksternal }\end{array}$ & Bobot $^{1}$ & Rating $^{2}$ & $\begin{array}{c}\text { Nilai } \\
\text { (bobot } x \text { rating) }\end{array}$ & Komentar \\
\hline $\begin{array}{l}\text { Peluang } \\
\text { Ancaman }\end{array}$ & & & & \\
\hline Total & & & & \\
\hline
\end{tabular}

Sumber: Analisis SWOT Teknik Membedah Kasus Bisnis, 2006

Keterangan :

1. Pemberian nilai bobot masing-masing faktor tersebut dengan skala (paling penting $=1,0$ dan tidak penting $=0,0$ ).

2. Rating untuk masing-masing faktor kekuatan dan peluang bersifat positif (semakin besar diberi rating +4 , tetapi semakin kecil diberi trating +1 ). Sedangkan nilai rating kelemahan dan ancaman adalah kebalikannya.

Caranya dengan menganalisis faktor internal dan eksternal dan mendapatkan nilai yang telah diolah, selanjutnya membuat matriks posisi kompetitif relatif dengan cara memasukkan angka yang telah diolah kedalam matriks yang terdapat empat area menjadi nilai IFAS dan nilai EFAS. Sehingga dari nilai tersebut dapat diketahui kekuatan dan peluang atau kelemahan dan ancaman yang dimiliki oleh usahatani tembakau samporis. Kemudian menggunakan Matriks Internal Eksternal (IE) untuk mengukur kekuatan internal perusahaan dan pengaruh eksternal yang dihadapi. Tujuan penggunaan model ini adalah untuk memperoleh strategi di tingkat korporat yang lebih detail.

\section{HASIL DAN PEMBAHASAN}

\section{Pendapatan Usahatani Tembakau Rajang Samporis di Desa Jelbuk Kecamatan Jelbuk Kabupaten Jember}

Pendapatan merupakan suatu hal yang sangat diharapakan oleh petani untuk memenuhi segala kebutuhan petani maupun keluarganya. Selain itu pendapatan juga merupakan alasan utama para petani menanam tembakau yaitu berupa keuntungan dari tembakau yang telah mereka tanam. Besar kecil nya pendapatan petani sangat tergantung pada jumlah biaya yang dikeluarkan untuk memproduksi tembakau dan juga tergantung pada jumlah tembakau dan harga yang berlaku dengan melihat kualitas dari tembakau tersebut. 
Tabel 3. Rata- rata Produktivitas, Harga Jual, dan Penerimaan Usahatani Tembakau Samporis di Desa Jelbuk Kecamatan Jelbuk Kabupaten Jember Tahun 2016.

\begin{tabular}{llr}
\hline No & \multicolumn{1}{c}{ Uraian } & Nilai \\
\hline 1 & Produktivitas (ton/ha) & 0,76 \\
2 & Harga jual (Rp/kg) & 23.018 \\
3 & Penerimaan (Rp/ha/musim) & 7.944 .129 \\
\hline
\end{tabular}

Sumber: Data Primer Diolah Tahun 201

Tabel 3. menunjukkan bahwa ratarata produktivitas usahatani tembakau samporis yang dihasilkan oleh petani tembakau samporis di desa Jelbuk yaitu 0,76 ton/ha. Angka tersebut menunjukkan bahwa setiap Hektar (ha) lahan yang ditanami tembakau samporis menghasilkan 0,76 Ton tembakau. Berdasarkan produktivitas tembakau rajang samporis tersebut, jika dibandingkan dengan proyeksi produktivitas tembakau pada Direktorat Jenderal Perkebunan Tahun 2016 yaitu sebanyak 1 Ton/Ha.

Bila dibandingkan dengan jumlah produktivitas tembakau rajang samporis yang ada di Desa Jelbuk Kecamatan Jelbuk Kabupaten Jember, maka dapat dikatakan masih belum bisa mencapai target atau masih tergolong rendah.

Penyebab utama jumlah produksi tembakau samporis yang masih rendah karena curah hujan yang tinggi yang menyebabkan banyak daun tembakau yang busuk sehingga produksi tembakau menurun. Penyebab lainnya adalah terdapat beberapa petani yang tidak mengikuti SOP (Standart Operating Procedure), seperti banyak petani yang tidak menggunakan pupuk urea karena mereka beranggapan bahwa lahan yang biaya produksi tembakau tersebut. Padahal jika tanah digunakan secara terus-menurus akan menyebabkan unsur hara tanah semakin berkurang. Maka dari itu, untuk permasalahan yang petama, perlu adanya peramalan cuaca yang tepat agar ketika tembakau ditanam tidak bersamaan dengan musim hujan yang mengancam kerugian petani tembakau samporis di Desa Jelbuk.

Sementara rata-rata harga jual tembakau samporis yaitu sebesar $\mathrm{Rp}$ $23.018 / \mathrm{kg}$. Nilai tersebut menunjukkan harga jual yang diperoleh dari hasil rata-rata harga penjualan tembakau samporis dari petikan pertama sampai ke empat, ke lima dan ada juga yang sampai pada petikan yang ke enam. Petani yang melakukan pemanenan atau pemetikan daun tembakau sebanyak empat kali berjumlah 2 orang petani, sedangkan yang melakukan pemetikan tembakau sebanyak lima kali adalah 9 orang. Sementara petani yang melakukan pemetikan sampai enam kali berjumlah 20 orang. Jadi petani paling banyak melakukan pemetikan sebanyak enam kali dalam satu kali musim tanam tembakau samporis. Rata-rata total penerimaan yang diperoleh para petani tembakau samporis yaitu sebesar $\mathrm{Rp}$ 7.944.129/ha/musim.

Tabel 4. Rata-rata Biaya Tetap, Biaya Variabel, dan Total Biaya per Hektar Usahatani Tembakau Samporis di Desa Jelbuk Tahun 2016.

\begin{tabular}{clr}
\hline No & \multicolumn{1}{c}{ Uraian } & \multicolumn{2}{c}{ Nilai (Rp/ha/musim) } \\
\hline 1 & Total Biaya Tetap (TFC) & 888.742 \\
2 & Total Biaya Variabel (TVC) & 4.966 .145 \\
3 & Total Biaya (TC) & 5.854 .887 \\
\hline
\end{tabular}

Sumber: Data Primer Diolah Tahun 2016 
Tabel 4. menyatakan bahwa rata-rata total biaya tetap (TFC) yang dikeluarkan oleh petani tembakau samporis yaitu sebesar Rp $888.742 / \mathrm{ha} /$ musim. Total biaya variabel (TVC) yang dikeluarkan petani untuk pemeliharaan atau untuk membeli sarana produksi usahatani tembakau samporis adalah sebesar Rp 4.966.145/ha/musim.
Kemudian Total Biaya (TC) yang didapatkan dari penjumlahan antara total biaya tetap (TFC) dengan total biaya variabel (TVC) usahatani tembakau samporis yang dikeluarkan oleh para petani di Desa Jelbuk. Besarnya Total Biaya (TC) pada usahatani tembakau ini yaitu Rp 5.854.887/ha/musim.

Tabel 5. Penerimaan berdasarkan Harga yang Diterima oleh Petani Tembakau Samporis di Desa Jelbuk Kecamatan Jelbuk Kabupaten Jember, Tahun 2016

\begin{tabular}{lcccc}
\hline \multirow{2}{*}{ No } & \multirow{2}{*}{ Petik ke } & \multicolumn{3}{c}{ Harga } \\
\cline { 2 - 5 } & & Tertinggi $(\mathbf{R p})$ & Terendah $(\mathbf{R p})$ & Rata-rata $($ Rp) \\
\hline 1 & 1 & 28.000 & 10.000 & 17.700 \\
2 & 2 & 32.000 & 13.000 & 23.000 \\
3 & 3 & 40.000 & 14.000 & 28.000 \\
4 & 4 & 40.000 & 18.000 & 29.000 \\
5 & 5 & 30.000 & 10.000 & 19.000 \\
6 & 6 & 30.000 & 10.000 & 11.000 \\
\hline & Rata-rata & $\mathbf{3 3 . 0 0 0}$ & $\mathbf{1 2 . 5 0 0}$ & $\mathbf{2 1 . 5 0 0}$ \\
\hline
\end{tabular}

Sumber: Data Primer diolah tahun 2016

Data diatas menjelaskan bahwa harga tembakau samporis dari petikan yang pertama sampai yang ke-enam berbeda-beda. Awal pemetikan harga masih rendah namun pada petikan yang kedua harga mulai naik selanjutnya petikan ketiga dan keempat merupakan petikan yang memiliki harga tertinggi dari petikan yang lain karena kualitas daun tembakau terbaik ada pada petikan yang tengah yaitu ketiga dan keempat. Sementara pada petika kelima dan keenam harga tembakau sudah mulai turun lagi. Rata-rata dari seluruh petikan tembakau harga tertinggi yaitu senilai $\mathrm{Rp} 33.000$ sementara rata-rata harga terendah tembakau dari seluruh petikan sebesar $\mathrm{Rp} 12.500$. Sedangkan Rata-rata dari seluruh petikan dan seluruh harga pada usahatani tembakau samporis ini yaitu Rp 21.500. Harga tembakau yang tinggi karena kualitas tembakau yang baik sehingga harganyapun juga tinggi, begitu pula sebaliknya.

Berdasarkan nilai penerimaan dan total biaya yang telah dipaparkan pada tabel sebelumnya, sehingga total pendapatan petani tembakau samporis di Desa Jelbuk pada tahun musim 2016 dapat diketahui sebagai berikut:

Tabel 6. Rata-rata Total Penerimaan, Total Biaya, dan Pendapatan Usahatani Tembakau Samporis di Desa Jelbuk Tahun 2016

\begin{tabular}{clc}
\hline No & \multicolumn{1}{c}{ Uraian } & Nilai (Rp/ha/musim) \\
\hline 1 & Penerimaan (TR) & 7.944 .129 \\
2 & Total Biaya (TC) & 5.854 .887 \\
3 & Pendapatan (п) & 2.089 .242 \\
\hline
\end{tabular}

Sumber: Data Primer Diolah Tahun 2016 
Munawaroh dkk: Analisis pendapatan dan strategi pengembangan....

Rata-rata total pendapatan yang diperoleh oleh petani tembakau samporis pada tahun 2016 yaitu sebesar $\mathrm{Rp}$ 2.089.242/ha/musim sehingga dapat disimpulkan bahwa usahatani tembakau samporis yang dilakukan oleh para petani di Desa Jelbuk adalah menguntungkan. Kriteria pengambilan keputusan dalam permasalahan tersebut adalah jika TR > TC menunjukkkan bahwa usahatani tembakau samporis di Desa Jelbuk adalah menguntungkan, sehingga dari penjelasan diatas maka hipotesis dalam penelitian ini bisa adalah diterima.

Tabel 7. Daftar Rata-Rata Pendapatan berdasarkan untung dan rugi yang Diterima Petani Tembakau Samporis Dalam 1 Kali Musim Tanam Di Desa Jelbuk Kecamatan Jelbuk Kabupaten Jember, Tahun 2016

\begin{tabular}{clcr}
\hline No & \multicolumn{1}{c}{ Uraian } & Jumlah Responden (N) & Nilai (Rp/ha/musim) \\
\hline 1. & Pendapatan (Untung) & 25 & 2.594 .000 \\
2. & Pendapatan (Rugi) & 6 & -858.000 \\
\hline
\end{tabular}

Sumber: Data primer diolah tahun 2016

Data diatas menyebutkan bahwa petani tembakau samporis di Desa Jelbuk ada beberapa yang mengalami kerugian. Terdapat 6 orang petani yang mengalami kerugian dengan nilai rata-rata kerugian yang dialami sebesar Rp $\quad$-858.000/ha/musim. Penyebab utama kerugian tersebut adalah cuaca yang tidak mendukung, petani yang menanam tembakau pada bulan akhir Juli sampai awal Agustus rata-rata mengalami kerugian karena saat proses pemanenan dan penjemuran curah hujan yang ada di desa Jelbuk sangat tinggi sehingga banyak kualitas tembakau yang menurun bahkan rusak karena terkena hujan yang melebihi batas kestabilan dalam berusahatani tembakau samporis.

Namun banyak petani yang mengalami untung yaitu sekitar 25 orang dengan nilai rata-rata sebesar $\mathrm{Rp}$ 2.294.000/ha/musim. Dari pendapatan tersebut dapat disimpulkan bahwa lebih banyak petani yang mengalami keuntungan dari pada kerugian, sehingga petani yang mengalami kerugian perlu untuk memperbaiki waktu penanamannya agar tidak merusak kualitas tembakau yang disebabkan oleh curah hujan yang tinggi yang datang ketika petani sedang dalam proses panen maupun pasca panen.

Efisiensi Penggunaan Biaya Produksi dan Tenaga Kerja pada Usahatani Tembakau Rajang Samporis

Efisiensi biaya produksi usahatani tembakau samporis digunakan untuk mengetahui apakah biaya yang digunakan untuk usahatani tembakau sudah dapat dikatakan efisien atau belum. Efisiensi biaya dihitung dengan menggunakan rumus $\mathrm{R} / \mathrm{C}$ ratio.

Tabel 8. Rata-rata Total Penerimaan, Total Biaya, dan Efisiensi Penggunaan Biaya Usahatani Tembakau Samporis di Desa Jelbuk Kecamatan Jelbuk Kabupaten Jember

\begin{tabular}{|c|c|c|}
\hline No & Uraian & Nilai \\
\hline 1 & Penerimaan (Rp/ha/musim) & 7.944 .129 \\
\hline 2 & Total Biaya (Rp/ha/musim) & 5.655 .516 \\
\hline 3 & R/C Ratio & 1,44 \\
\hline
\end{tabular}

Sumber: Data Primer Diolah Tahun 2016 
Dari Tabel 8 nilai rata-rata total penerimaan (TR) yang diterima petani dalam usahatani tembakau samporis sebesar Rp 7.944.129/ha/musim. Nilai tersebut diperoleh dari hasil antara produksi tembakau samporis dengan harga jual tembakau tersebut. Dalam usahatani tembakau samporis terdapat beberapa kali proses pemanen daun tembakau. Pemanenan tersebut dilakukan ada yang 4 kali petik, 5 kali petik, bahkan ada yang sampai 6 kali petik daun tembakau. Masing-masing petikan memiliki harga yang berbeda-beda, pada petikan pertama kualitas dan jumlah tembakau masih rendah, biaya penerimaan yang dihasilkan pada petikan pertama kali rendah. pada petikan kedua kualitas dan jumlah tembakau mulai naik dan pada pemetikan ketiga kualitas dan jumlah tembakau mengalami peningkatan tertinggi. Sementara pada pemetikan ke 4, 5, dan 6 mutu dan jumlah tembakau terus menurun.

Rata-rata total biaya yang dikeluarkan petani yaitu sebesar $\mathrm{Rp}$ 5.655.516/ha/ musim. Petani yang melakukan pemetikan hingga petikan yang ke 6 selain menambah total penerimaan, juga menambah biaya tenaga kerja yaitu biaya pemetikan, perajangan dan penjemuran. Namun rata-rata pemetikan tembakau samporis yang dilakukan oleh petani yaitu sampai pada pemetikan ke 6 saja. Total biaya didapatkan dari penjumlahan antara total biaya variabel (TVC) dengan total biaya tetap (TFC). Total biaya produksi yang semakin rendah dapat meningkatkan efisiensi suatu usahatani, sehingga diharapkan para petani tembakau samporis dapat meminimalkan total biaya yang dikeluarkan dalam usahataninya.

Tabel diatas menunjukkan bahwa rata-rata total biaya yang dikeluarkan petani dalam usahatani tembakau samporis adalah efisien. Hal tersebut dapat dibuktikan dari nilai $\mathrm{R} / \mathrm{C}$ ratio yang memiliki nilai lebih dari 1. Untuk menganalisis $\mathrm{R} / \mathrm{C}$ ratio dilakukan dengan pembagian antara nilai rata-rata total penerimaan (TR) dengan rata-rata total biaya (TC) yang dikeluarkan oleh petani. Nilai R/C ratio sebesar 1,44 menunjukkan bahwa hasil analisis tersebut dapat dinyatakan efisien karena nilainya lebih dari satu. Artinya usahatani tembakau samporis di Desa Jelbuk Kecamatan Jelbuk adalah layak untuk diusahakan. Kriteria pengambilan keputusan pada permasalahan ini adalah sebagai berikut: jika $\mathrm{R} / \mathrm{C}$ ratio $\leq 1$, maka penggunaan biaya produksi pada usahatani tembakau samporis adalah tidak efisien, jika $\mathrm{R} / \mathrm{C}$ ratio $>1$, maka penggunaan biaya produksi pada usahatani tembakau samporis adalah efisien. Karena nilai $\mathrm{R} / \mathrm{C}$ ratio adalah sebesar 1,44 maka penggunaan biaya produksi pada usahatani tembakau samporis adalah efisien. Berdasarkan penjelasan tersebut maka hipotesis dalam penelitian ini adalah diterima.

Rata-rata nilai total $\mathrm{R} / \mathrm{C}$ ratio untuk petani tembakau samporis di Desa Jelbuk Kecamatan Jelbuk tahun musim 2016 adalah sebesar 1,44. Angka tersebut artinya rata-rata biaya yang dikeluarkan oleh petani tembakau samporis di Desa Jelbuk adalah efisien. Nilai $\mathrm{R} / \mathrm{C}$ ratio sebesar 1,44 dapat diartikan bahwa setiap pengeluaran biaya produksi sebesar Rp 1, maka akan memperoleh penerimaan sebesar $\mathrm{Rp} 1,44$ dan pendapatan yang diperoleh sebesar $\mathrm{Rp}$ 0,44.

Efisiensi biaya sangat erat kaitannya dengan total biaya yang dikeluarkan oleh petani tembakau samporis. Biaya produksi paling besar adalah pengeluaran pada biaya variabel yaitu sebesar $\mathrm{Rp}$ 4.966.000. Ratarata biaya tenaga kerja petani tembakau samporis adalah $\mathrm{Rp}$ 3.933.000. Upah tenaga kerja dalam keluarga dihitung sama dengan upah tenaga kerja luar keluarga. Hal ini karena tenaga yang dikeluarkan untuk proses produksi dihargai sama tanpa memandang siapa yang melakukannya, dalam masalah ini upah tenaga kerja tidak hanya dihitung secara finansial saja namun lebih detail lagi yaitu secara ekonomi, jadi dihitung berdasarkan kebutuhan tenaga kerja yang dibutuhkan dalam proses pengoalahan usahatani tembakau samporis. 
Tabel 7. Rata-rata R/C Ratio $>1$ dan $<1$ Berdasarkan Pendapatan yang Diterima Petani Tembakau Samporis dalam 1 Kali Musim Tanam Di Desa Jelbuk Kecamatan Jelbuk Kabupaten Jember, Tahun 2016

\begin{tabular}{cccc}
\hline No & R/C Ratio & Jumlah Responden $(\mathrm{N})$ & Nilai (Rp/Ha/Musim) \\
\hline 1 & $>1$ & 25 & 1,61 \\
2 & $<1$ & 6 & 0,76 \\
\hline
\end{tabular}

Sumber :Data Primer Diolah 2016

Dari Tabel 7 disimpulkan bahwa tembakau samporis di Desa Jelbuk memiliki nilai $\mathrm{R} / \mathrm{C}$ Ratio rata-rata $>1$ yaitu dengan nilai 1,61. Angka tersebut menunjukkan bahwa sebanyak 25 petani dapat menggunakan biaya usahataninya secara efisien karena $\mathrm{R} / \mathrm{C}$ ratio $>1$. Sementara Nilai R/C Ratio yang memiliki nilai rata-rata $<1$ dengan nila 0,76 . Hal tersebut dapat diartikan bahwa sebanyak 6 petani yang menggunakan biaya usahataninya secara tidak efisien karena $\mathrm{R} / \mathrm{C}$ ratio $<1$.

\section{Prospek dan Rancangan Strategi Pengembangan Usahatani Tembakau Rajang Samporis \\ Analisis SWOT dilakukan berdasarkan} asumsi bahwa suatu strategi yang efektif akan memaksimalkan kekuatan dan peluang serta meminimalkan kelemahan dan ancaman yang ada dalam usahatani tersebut. Tahap awal dalam analisis ini yaitu mengidentifikasi faktor-faktor kondisi lingkungan internal dan eksternal yang dimiliki oleh usahatani tembakau samporis. Faktor-faktor tersebut dapat dijelaskan pada tabel berikut.

Tabel 8. Analisis Faktor Strategi Internal dan Eksternal Usahatani Tembakau Samporis

\begin{tabular}{|c|c|c|c|}
\hline \multicolumn{4}{|c|}{$\begin{array}{l}\text { Faktor-faktor Strategi Internal } \\
\end{array}$} \\
\hline \multicolumn{2}{|c|}{ Strength $(\mathbf{S})$} & \multicolumn{2}{|l|}{ Weaknesess (W) } \\
\hline Ketersediaan bibit selalu ada & $\mathrm{S}_{1}$ & Pengaruhkelebihan irigasi & $\mathrm{W}_{1}$ \\
\hline Teknologi usahatani memudahkan & $\mathrm{S}_{2}$ & & $\mathrm{~W}_{2}$ \\
\hline petani dan menghemat biaya & & Biaya tenaga kerja yang tinggi & \\
\hline Pemakaian pupuk berimbang & $\mathrm{S}_{3}$ & Biaya saprodi yang tinggi & W3 \\
\hline Ketersediaan tenaga kerja terampil & $\mathrm{S}_{4}$ & $\begin{array}{l}\text { Teknologi pasca panen kurang } \\
\text { efisien }\end{array}$ & $\mathrm{W}_{4}$ \\
\hline Biaya pengangkutan yang murah & $\mathrm{S}_{5}$ & Rendemen tembakau rendah & $\mathrm{W}_{5}$ \\
\hline Harga jual yang tinggi & $\mathrm{S}_{6}$ & Pemasaran hanya ke pengepul saja & $\mathrm{W}_{6}$ \\
\hline \multicolumn{4}{|c|}{ Faktor-faktor Strategi Eksternal } \\
\hline \multicolumn{2}{|c|}{$\begin{array}{l}\text { Opportunities (O) } \\
\end{array}$} & \multicolumn{2}{|c|}{ Threats (T) } \\
\hline Keadaan geografis yang strategis & $\mathrm{O}_{1}$ & $\begin{array}{l}\text { Informasi harga pasar kurang } \\
\text { terbuka }\end{array}$ & $\mathrm{T}_{1}$ \\
\hline Seluruh tembakau terjual & $\mathrm{O}_{2}$ & Intruksi bahaya merokok & $\mathrm{T}_{2}$ \\
\hline Rutin dalam pembinaan usaha tani & $\mathrm{O}_{3}$ & Infrastruktur kurang memadai & $\mathrm{T}_{3}$ \\
\hline Peran kelompok tani yang aktif & $\mathrm{O}_{4}$ & Perubahan cuaca tidak mendukung & $\mathrm{T}_{4}$ \\
\hline $\begin{array}{l}\text { Kebijakan pemerintah yang } \\
\text { mendukung }\end{array}$ & $\mathrm{O}_{5}$ & $\begin{array}{l}\text { Persaingan pasar menyebabkan } \\
\text { harga kurang memuaskan. }\end{array}$ & $\mathrm{T}_{5}$ \\
\hline
\end{tabular}

Sumber: Data Primer Diolah Tahun 2016

Hasil perhitungan nilai faktor-faktor kondisi internal dan nilai faktor-faktor kondisi eksternal pada usahatani tembakau samporis maka dapat dikompilasikan kedalam matriks posisi kompetitif relatif pada gambar berikut: 


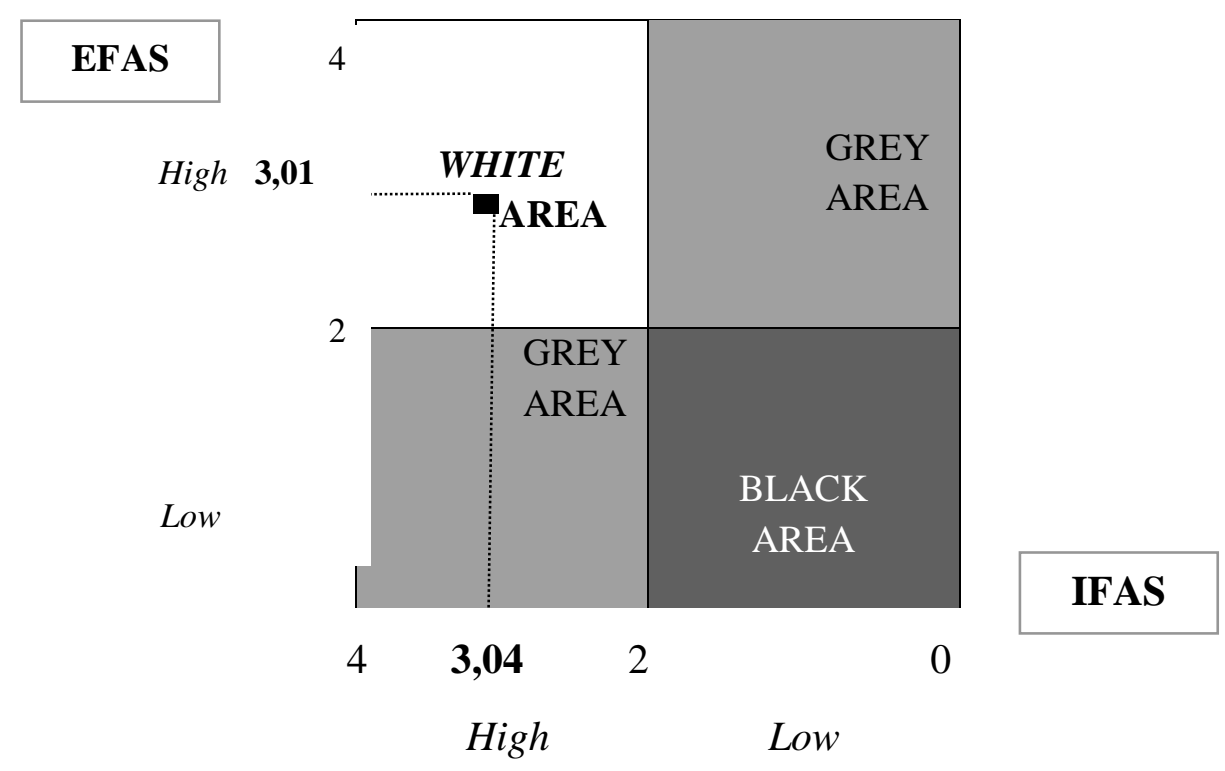

Gambar 1. Diagram Matrik Posisi Kompetitif Relatif Usahatani Tembakau Samporis

Berdasarkan hasil analisis faktorfaktor strategi internal pada usahatani tembakau samporis diperoleh nilai IFAS sebesar 3,04 dan hasil analisis faktor-faktor strategi eksternal usahatani tersebut diperoleh nilai EFAS sebesar 3,01. Nilai tersebut menempatkan usahatani tembakau samporis dalam posisi White Area (Bidang KuatBerpeluang)yang artinya usahatani tembakau samporis di Desa Jelbuk memiliki peluang pasar yang prospektif dan memiliki kompetensi untuk terus dikembangkan. Kekuatan yang dimiliki usahatani tembakau samporis yaitu ketersediaan bibit, teknologi usahatani, pemakaian pupuk, ketersediaan tenaga kerja, biaya pengangkutan, dan harga jual. Sedangkan peluang yang dimiliki yaitu keadaan geografis (iklim), seluruh tembakau terjual, pembinaan usahatani, peran kelompok tani, dan kebijakan pemerintah. Fokus strategi yang tepat bagi usahatani tembakau samporis dalam mengembangkan usahanya adalah strategi yang agresif dengan memaksimalkan kekuatan yang dimiliki sehingga dapat memanfaatkan peluang yang ada.

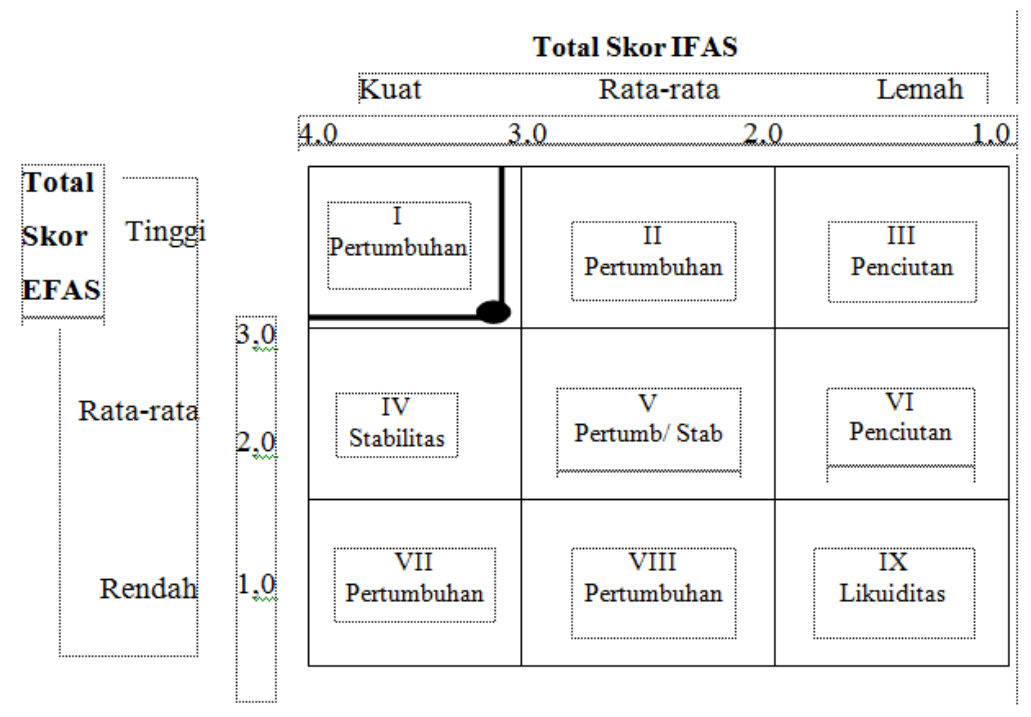

Gambar 2. Matrik Internal Eksternal (IE) Usahatani Tembakau Samporis di Desa Jelbuk 
Gambar 2 menunjukan nilai faktor strategis internal diperoleh hasil 3,04 dan faktor strategis eksternal diperoleh hasil 3,01. Menunjukkan posisi usahatani tembakau samporis di Desa Jelbuk Kecamatan Jelbuk Kabupaten Jember berada pada daerah I (satu) yaitu pertumbuhan. Hal ini menunjukkan bahwa strategi yang digunakan oleh Usahatani tembakau samporis adalah strategi pertumbuhan Konsentrasi melaluiIntegrasi Vertikal. Usahatani tembakau samporis tersebut berada pada pertumbuhan dengan meningkatkan kekuatan usahataninya. Integrasi dapat dicapai baik melalui sumber daya internal maupun eksternal. Integrasi vertikal dapat dicapai dengan cara backward integration (mengambil alih fungsi supplier khususnya pembibitan) atau dengan cara forward integration (mengambil alih fungsi distributor khususnya pengepul). Jadi backward integration dicapai dengan petani tidak lagi membeli bibit namun mencoba untuk melakukan pembibitan tembakau sendiri dari benih yang dimiliki. Selain itu forward integration dilakukan dengan cara petani tidak lagi menjual tembakau samporis kepada pengepul namun langsung kepada pihak gudang. Dengan cara ini maka petani lebih mandiri dan pendapatan petani dalam berusahatani tembakau samporis bisa semakin meningkat.

\section{KESIMPULAN}

1. Rata-rata pendapatan petani tembakau samporis di Desa Jelbuk Kecamatan Jelbuk Kabupaten Jember sebesar Rp 2.089.242/ha/musim. Maka usahatani tembakau tersebut adalah menguntungkan.

2. Penggunaan biaya produksi pada usahatani tembakau samporis di desa Jelbuk Kecamatan Jelbuk Kabupaten Jember yaitu sebesar 1,44. Maka usahatani tersebut adalah efisien.

3. Analisis SWOT yang menunjukkan bahwa usahatani tembakau samporis di Desa Jelbuk Kecamatan Jelbuk Kabupaten
Jember berada pada posisi White Area (Bidang Kuat-Berpeluang).

\section{DAFTAR PUSTAKA}

Badan Pusat Statistik. 2015. Jawa Timur dalam Angka 2015. Surabaya:BPS Jawa Timur

Badan Pusat Statistik. 2015. Kabupaten Jember dalam Angka 2015. Jember: BPSKabupaten Jember

Direktorat Jenderal Perkebunan. 2015. Rencana Kinerja Tahunan (RKT). Jakarta: Direktorat Jenderal Perkebunan Kementria Pertanian.

Hernanto,F. 1996. Ilmu Usaha Tani. Jakarta: Penebar Swadaya.

Nazir, Mohammad. 2009. Metode Penelitian. Jakarta: Penerbit Ghalia Indonesia.

Rangkuti, Freddy. 2006. Analisis SWOT Teknik Membedah Kasus Bisnis. Jakarta: Gramedia Pustaka Utama.

Soekartawi, 1995. Analisis Usahatani. Jakarta: Universitas Indonesia Press 